\title{
The Making of Modern Malayalam Prose and Fiction: Translations from European Languages into Malayalam in the First Half of the Twentieth Century
}

K.M. Sherrif

\begin{abstract}
Translations from European languages have played a crucial role in the evolution of Malayalam prose and fiction in the first half of the Twentieth Century. Many of them are directly linked to the sociopolitical movements in Kerala which have been collectively designated 'Kerala's Renaissance.' The nature of the translated texts reveal the operation of ideological and aesthetic filters in the interface between literatures, while the overwhelming presence of secondary translations indicate the hegemonic status of English as a receptor language. The translations never occupied a central position in the Malayalam literature and served mostly as mere literary and political stimulants.
\end{abstract}

Keywords: Translation - evolution of genres, canon - political intervention

The role of translation in the development of languages and literatures has been extensively discussed by translation scholars in the West during the last quarter of a century. The proliferation of diachronic translation studies that accompanied the revolutionary breakthroughs in translation theory in the mid-Eighties of the Twentieth Century resulted in the extensive mapping of the intervention of translation in the development of discourses and shifts of ideological paradigms in cultures, in the development of genres and the construction and disruption of the canon in literatures and in altering the idiomatic and structural paradigms of languages.

One of the most detailed studies in the area was made by Andre Lefevere (1988, pp 75-114) Lefevere showed with convincing 
examples from a number of literary systems how translation makes decisive interventions in literary systems and the role played by translated literature in literary polysystems. A large number of translations are made by authors who are eager to introduce a particular genre or mode (in which they have already made, or wish to make, experiments on their own) into a literary system. They would, naturally, like to invoke the masters in that particular genre or mode in the source literary system. Translation acquires a more social motive when enterprising translators who inhabit relatively young languages/literary systems import texts from more established languages/literary systems for the enrichment of various discourses in their system. Such well-intentioned attempts can go to extremes, as when Czech literature (like other discourses in the Czech language) at the end of the Nineteenth century virtually became a clone of contemporary German literature (Macura, 1990). In this case literary translation occupied only a small percentage of the total volume of translation. Even today knowledge texts in translation outnumber their literary counterparts many times over (Venuti, P.67) But translation is often called upon to perform political roles too, the earliest examples in history for which are Bible translations in various languages of the world. A large part of the American translation scholar Eugene A Nida's work on translation deals with the strategies of Bible translation and their implications in the target culture. A more recent example is the Communist Manifesto. Apart from such 'core texts' like the Bible or the Communist Manifesto, there are a large number of less known translated texts which are made to serve the interests of dynamic socio-political movements in cultures. Nationalist and Communist movements in various cultures have extensively used translated texts for their immediate or longterm objectives. Revivalist movements have also used translated texts for similar objectives, although to a lesser extent.

Translation can also seriously disrupt or dislocate the structural patterns of the target language or the aesthetic paradigms of the target literary system. The classical instance pointed out by Lefevere is translation from Arabic to Turkish. In many cases 'progressive' elements often view these effects are beneficial to the 
culture, while they are vehemently decried by more conservative elements including cultural purists. The current tendency is to regard such disruptions and dislocations as natural phenomena. No academy can today dictate language use or literary practice.

Although the history of European colonialism begins in many regions of what is today the state of Kerala as early as the late Eighteenth Century, translation from English on a considerable scale took off only as late as the beginning of the Twentieth Century. The reasons are obvious. The rump of the Malayalam literary elite continued to operate in a largely pre-colonial literary atmosphere, while the new English-reading elite had little interest in using translations to make interventions in Malayalam literature. Writers like $\mathrm{O}$ Chandu Menon short-circuited the process by directly imitating English novels rather than by translating any into Malayalam.

The proliferation of translations into Malayalam from the beginning of the Twentieth Century can be directly related to the socio-political movements in Kerala during the period which have been collectively designated 'Kerala's Renaissance.' The reformist movements among the various religious communities of the Malayalam speaking-territories, the anti-caste movements, the emerging Malayali nationalism and the politicization of workers and peasants which culminated in the formation of the Kerala unit of the Communist Party of India in 1939 are the chief ingredients of the Kerala Renaissance. The exhaustive catalogue of translations into Malayalam compiled by K M Govi and published by the Kerala Sahitya Akademi in 1995 helps in discerning some of the major trends in translation into Malayalam in the Twentieth Century. It will be useful to take 1960 as a cut-off year as it marks the subsiding of the first wave of Leftist politics in Kerala and the beginning of modernism in Malayalam literature.

One of the most interesting facts that emerge from an examination of these translations is that although English is the predominant source language, Russian and French have been widely 
represented. As can be expected, fiction dominates the list. More than a dozen works each of Balzac, Maupassant, Zola, Tolstoy and Gorky were translated into Malayalam during this period. Other major authors include Dostoevsky, Turgenev, Gogol, Chekhov, Sholokhov and Poliyev in Russian and Voltaire, Hugo, Dumas, Jules Verne and Anatole France in French. All of Ibsen's plays also came into Malayalam during this period. It is easy to relate these translations to the rise of social realism in Malayalam fiction in the Thirties on the one hand and the political and cultural assertion of the Communist Party on the other. The translations of the works of American fictionists Howard Fast, Upton Sinclair and John Steinbeck and the Chinese fictionist Lu Xun also comes into this frame. Among the translations during this period figure a smattering of what Left-leaning intellectuals during those times branded 'anticommunist literature.' Koestler's Darkness at Noon, Orwell's Animal Farm, Narakov's Chain of Terror and Pasternak's Doctor Zhivago may be considered representative.

An aesthetic filter (the kind described by Lefevere as decisive in translation) appears to have prevented the translation of what are distinctly modernist texts from European languages into Malayalam during this period. The only possible exception is a novel of Pirandello's translated by A Balakrishna Pillai. The title of the translation is given as Omanakal (The Beloved) in the catalogue, while the original title is not mentioned. The filter was faithfully guarding the frontiers Malayalam literature, in which Modernist experiments in both poetry and fiction emerged only in the mid-Sixties, and those in drama only in the early Seventies. Pulimana Parameswaran Pillai's Samatvavadi (The Socialist, 1940) and C J Thomas's Aayirathi Orunootti Irupathezhil Crime lrupathettu (Crime No. Twenty Eight of Eleven Hundred and Twenty Seven, 1951), although they are still among the most symptomatic expressionist plays in the language, can only be considered flashes in the pan.

Another interesting feature of translations during this period is that the overwhelming majority of the translations have 
come through English, with the exception of a few from Russian. As a result, the translations were putting tremendous pressure on Malayalam grammar, usage and lexis, as Kuttikrishna Marar, the Malayalam critic regretfully notes in Malayalashaili (Malayalam Usage, 1942), his monumental work on Malayalam usage. Early changes were visible in journalism, but soon the literary language too came under assault from English. Mostof the 'new fangled' expressions borrowed from English that Marar denounced in his book are today part of accepted Malayalam usage.

Perhaps the most influential single work that influenced Malayalam usage is Nalappattu Narayana Menon's translation of Victor Hugo's magnum opus Les Miserables as paavangal. Like the French texts that entered the Malayalam literary system a little later in the mid-Thirties of the century, paavangal was also an indirect translation, Isabel F Hapgood's English translation being the source text. Kuttippuzha Krishnappillai's study of paavangal (1958) is the first symptomatic translation study in Malayalam. Like the modernist experiments in drama in Malayalam, Kuttippuzha's essay was much ahead of it's times. Nearly a quarter of a century before translation studies in the West seriously started discussing the interventions made by translation in the development of languages and literatures, Kuttippuzha showed with telling examples how translations from English could give Malayalam prose and fiction a new strength and vitality.

\section{REFERENCES}

Govi, K M. 1995. Malalyala Granthasooji (Index of Books Published in Malayalam). Thrissur: Kerala Sahitya Akademi.

Hapwood, Isabel F. 2008. trans. Les Miserables. By Victor Hugo. 1862. 5 Vols. New York:Thomas Y Cromwell \& Co., 1887. Project Gutenberg. June 22, 2008. 18 August, 2012. http://www.gutenberg. org/files/135/135-h/135-h.htm.

Krishnappillai, Kuttippuzha. 2000. “Paavangal.” Kuttippuzhayude 
Prabandhangai'(Essays by Kuttippuzha). 1990. Rpt. Thrissur: Kerala Sahitya Akademi. pp. 67-84.

Lefevere, Andre. 1988. "Beyond Interpretation or the Business of (Re)writing." Essays in Comparative Literature. Calcutta: Papyrus.

Macura, Vladimir. 1990. "Culture as Translation." In Trnslation, History, Culture. Ed. Susan Bassnett and Andre Lefevere. London: Routledge. PP. 64-70.

Marar, Kuttikrishna. 1985. Malayalashaili (Malayalam Usage). 1942. Rpt. Kozhikode: Mathrubhumi Books.

Menon, Nalappattu Narayana. trans. Paavangal (Les Miserables ).By Victor Hugo. 3 Vols. Thrissur: Yogakshemam, 1925-'28.

Parameswaran Pillai, Pulimana. 1966. Samatvavadi (The Socialist). 1940. Rpt. Thrissur: G Sankara Pillai Memorial for Theatre Studies.

Thomas, C J. 1982. Ayiraihi Orunootti Irupathettil Crime Irupathezhu (Crime Number Twenty Seven of One Thousand One Hundred and Twenty Eight). 1954. Kottayam: DC Books.

Venuti, Lawrence. 1995. The Scandals of Translation. London: Routledge.

(Paper presented in the Seminar, "Growth of Malayalam Language and the Role of Knowledge Text Translation" on January 29, 2011.) 